\title{
Relationships between Psychidae communities (Lepidoptera: Tineoidea) and the ecological characteristics of old-growth forests in a beech dominated landscape
}

\author{
Stefano SCALERCIO ${ }^{1}$, Teresa BONACCI ${ }^{2}$, Rosario TURCO ${ }^{1}$ and Vincenzo BERNARDINI ${ }^{1}$ \\ ${ }^{1}$ Consiglio per la ricerca in agricoltura e l'analisi dell'economia agraria, Unità di ricerca per la selvicoltura in ambiente \\ mediterraneo, contrada Li Rocchi, I-87036 Rende (CS), Italy; e-mails: stefano.scalercio@entecra.it, rosario.turco@entecra.it, \\ vincenzo.bernardini@entecra.it \\ ${ }^{2}$ Dipartimento di Biologia, Ecologia e Scienze della Terra, Università della Calabria, Via P. Bucci, I-87036 Rende (CS), Italy; \\ e-mail: teresa.bonacci@unical.it
}

Key words. Lepidoptera, Psychidae, biodiversity, biological conservation, forest planning, old-growth, Italy

\begin{abstract}
Several studies address the question of which forest attributes are most important for the conservation of biodiversity. Unfortunately, there are no unequivocal answers because the response of a biological group to changes in forest structure depends on its natural history and scale of organization. It is important to increase our knowledge of the potential relationships between under studied groups of species and forest variables in order to adopt timber harvesting strategies not detrimental to biodiversity, especially in old-growth forests. We assessed the importance of 10 forest attributes and old-growth for Psychidae (Lepidoptera) species and communities. Research was carried out in 12 forest stands in a mountainous beech dominated landscape in southern Italy, in the middle of the Mediterranean Basin. Samples were collected in 2001 and 2013 and data were merged after pairwise comparison analyses that confirmed the long term stability of communities. Correspondence Analysis, Cluster Analysis and non-parametric Spearman Rank Order Correlation were used to identify determinants of Psychidae abundance and diversity. We collected 2,732 Psychidae belonging to 8 species. Correspondence analysis identified old-growth as the main determinant of communities. Most significant attributes for individual species were beech dominance, diameter at breast height and its standard deviation. For Taleporia defoliella there were positive correlations with these forest parameters, whereas for Psyche crassiorella the correlations were negative. This study underlined the importance of forest attributes associated with old-growth forests for sustaining biodiversity. These findings indicate the need to incorporate these attributes in forest planning, especially those aspects that are easily recognizable such as the number of large trees.
\end{abstract}

\section{INTRODUCTION}

There is a large body of literature on the relationships between biodiversity and forests attributes that investigate the parameters associated with species richness (Michel \& Winter, 2008; Moning \& Müller, 2009; Blasi et al., 2010; Fritz \& Heilmann-Clausen, 2010; Janssen et al., 2011), especially of declining species (Nieto \& Alexander, 2010).

Structural parameters of forest are known to be important determinants of plant and animal diversity (Blasi et al., 2010). Forest age determines lichen, mollusc and bird diversity (Moning \& Müller, 2009), tree species composition affects the composition of animal communities (Ostaff \& Quiring, 2000; Cherkaoui et al., 2009; Janssen et al., 2011), and tree density and basal area affect diversity in tropical dry forests (Sagar \& Singh, 2006). Microhabitat diversity seems to be one of the most important parameters linked to high levels of biodiversity, especially in old-growth forests (Michel \& Winter, 2008; Fritz \& Heilmann-Clausen, 2010).
The amount of dead wood appears to be a good predictor of saproxylic beetle diversity (Bonacci et al., 2012; Lachat et al., 2012; Redolfi De Zan et al., 2014). Unfortunately, it is not always possible to extend the outcome for a given attribute to whole forest biodiversity because natural history and home range of organisms, and scale of observation can strongly affect relationships between biodiversity and forest attributes (Summerville et al., 2003; Redolfi De Zan et al., 2014). Paradigms of island biogeography and landscape ecology are evoked to explain diversity and species abundance in fragmented forests. In some cases data are in agreement with its postulates as is recorded for moths (Usher \& Keiller, 1998; Fuentes-Montemayor et al., 2012), but not in other cases, for example, birds (Cherkaoui et al., 2009). Tree species diversity influence the composition of lepidopteran communities at fine scales (Ostaff \& Quiring, 2000), whereas as at larger scales other determinants 
suchas biogeographic history and landscape heterogeneity are important (Summerville et al., 2001, 2003).

Often insects are utilized as bioindicators because they have a key role in ecological functioning of forests. They are detritivores, defoliators, prey for vertebrates, pollinators, etc. Furthermore there are changes in the species composition and abundance in their communities in response to environmental perturbations. Ground beetles respond to forest management (Negro et al., 2013), saproxylic beetles are investigated because of their importance from a conservation point of view (Nieto \& Alexander, 2010; Mazzei et al., 2011) and Lepidoptera are used to describe spatial and temporal patterns in forest biodiversity (Usher \& Keiller, 1998; Summerville et al., 2001, 2003), and so on.

Lepidoptera is a hyper-diverse insect order, including several families of which only the so called macrolepidoptera have a well-defined taxonomy and well-known ecology, and often used in ecological studies (New, 2004; Summerville et al., 2004; Scalercio et al., 2007). The family Psychidae (Lepidoptera: Tineoidea), with 514 species in the Palaearctic Region (Sobczyk, 2011), have a natural history quite different from that of other Lepidoptera. Larvae live in a bag of variable architecture built of plant detritus, which sometimes is useful for species identification. Females are usually wingless and sometimes without any kind of appendages. Males are small, brownish or greyish, rarely larger than one centimeter, with a very low dispersal ability. Some species are parthenogenetic. Larvae pupate inside their bag and females of many species also lay eggs inside the bags (Rhainds et al., 2009). This family is often neglected by lepidopterists because species are difficult to identify and rarely collected as adults. Few species are well known other than the pests and little is known about the ecology of most of them. However, knowledge of their relationships with forest cover could add a new piece to the puzzle of forest ecosystem functioning. Some characteristics of Psychidae are very useful for describing forest habitats. They have a very low dispersal power and thus can be a powerful tool for describing forest dynamics at small spatial scales of tens of meters. Usually the diversity and community composition of phytophagous Lepidoptera is associated with the diversity and composition of flora, but larvae of European Psychidae often feed on detritus, algae and lichens or are polyphagous (Hättenschwiler, 1997). Thus they are more likely than other Lepidoptera to respond to plant structure and microhabitat characteristics than floristic composition. It is important to investigate as many animal groups with different ecological needs as possible to delineate the detailed dynamics of biodiversity in forest ecosystems.

We characterized the Psychidae community in Mountainous beech forests, a forest type covering $4 \%$ of the forested area in Europe (Barbati et al., 2014). The area studied is located in the middle of the Mediterranean Basin, at the southern edge of the range of beech. We tested the hypothesis that the structure of communities of Psychidae are associated with forest attributes. Furthermore, we investigated the relationships of the communities and individual species with forest attributes characterizing old-growth beech forests in order to propose appropriate management strategies. In detail, the aims of this study were: (1) to assess the adaptation of Psychidae communities in terms of the fine scale attributes of beech forests; (2) to identify forest attributes driving Psychidae communities; (3) to evaluate Psychidae as an indicator of old-growth beech forests.

\section{MATERIAL AND METHODS}

\section{Study area}

The study area is situated in the locality Passo della Crocetta at 900-980 m a.s.1., in the Catena Costiera mountains, Calabria, Southern Italy (Fig. 1). The soil is arenaceous-siliceous, usually with a good depth $(80-100 \mathrm{~cm})$, loose and permeable in upper horizons. It is moderately fertile, suitable for grazing, farming and forest cultivation. According to the Soil Map of Italy (Mancini, 1966) it belongs to the brown Mediterranean soil of mesophilous forests. The climate is submontane Mediterranean, with mild and rainy winters and hot and dry summers (Ciancio, 1971). Annual mean temperature over the last 30 years was $13^{\circ} \mathrm{C}$, with an average annual precipitation of $1550 \mathrm{~mm}$ and 110 rainy days. Dryness of summer months is mitigated by high humidity caused by orographic fogs due to western humid winds encountering the mountains of the Catena Costiera. Forest cover is dominated by Fagus sylvatica L. In Europe beech forests have a key role in the conservation of biodiversity (Annex 1, Habitats Directive, 92/43/EEC) and their conservation value is greatest in the south because the beech forests there are ecologically and biogeographically older than those in central and northern Europe (Walentowski et al., 2014). According to Barbati et al. (2014) the beech forest studied can be classified as Apennine-Corsican mountainous beech forest (EFTs - Type level 7.3). For the Mediterranean Basin there are few studies on the relationships between biodiversity and beech forest attributes (Negro et al., 2013; Redolfi De Zan et al., 2014), although they harbor unique species assemblages including endemics and relict species (Walentowski et al., 2014). In the area studied some patches of forest cover have structural attributes typical of an old-growth forest (Bauhus et al., 2009). Very large beech trees dominated in some patches, with Ruscus aculeatus L. and Ilex aquifolium L. in the understory, a high above ground biomass and deep layer of litter on the forest floor. There are isolated but not rare trees of Acer pseudoplatanus L., Quercus cerris L., Castanea sativa Mill., Corylus avellana L. and Fraxinus spp. in the tree layer. Along watersheds Alnus cordata Desf. is more common than in other areas. Small patches of 60 year old Pinus pinaster Aiton are present in the area as consequence of reforestation of pastureland. The forest cover is homogeneous with only sporadic small clearings of various origin where Pteridium aquilinum (L.) Kuhn, Rubus sp.pl., Sambucus nigra L. and Erica arborea L. dominate depending on local edaphic conditions. Human disturbance is low and heterogeneous. The area is traversed by Provincial Road n. 35, but vehicular traffic is very scarce.

\section{Description of stands}

We investigated Psychidae community along a beech-dominated forest transect ranging from patches having characteristics of old-growth forests to highly disturbed patches such as areas reforested with conifers. Topography, species composition of the tree layer and forest structure were studied in a buffer zone of $15 \mathrm{~m}$ around 12 guard railed sections of Provincial Road n. 35 in which Psychidae were collected (Fig. 1). Stands chosen were small in area with a diameter of $1.25 \mathrm{~km}$ and variation in altitude of $80 \mathrm{~m}$ (Table 1). In such small areas we were able to keep altitude and macroclimate similar and so eliminate the biogeographic effects 


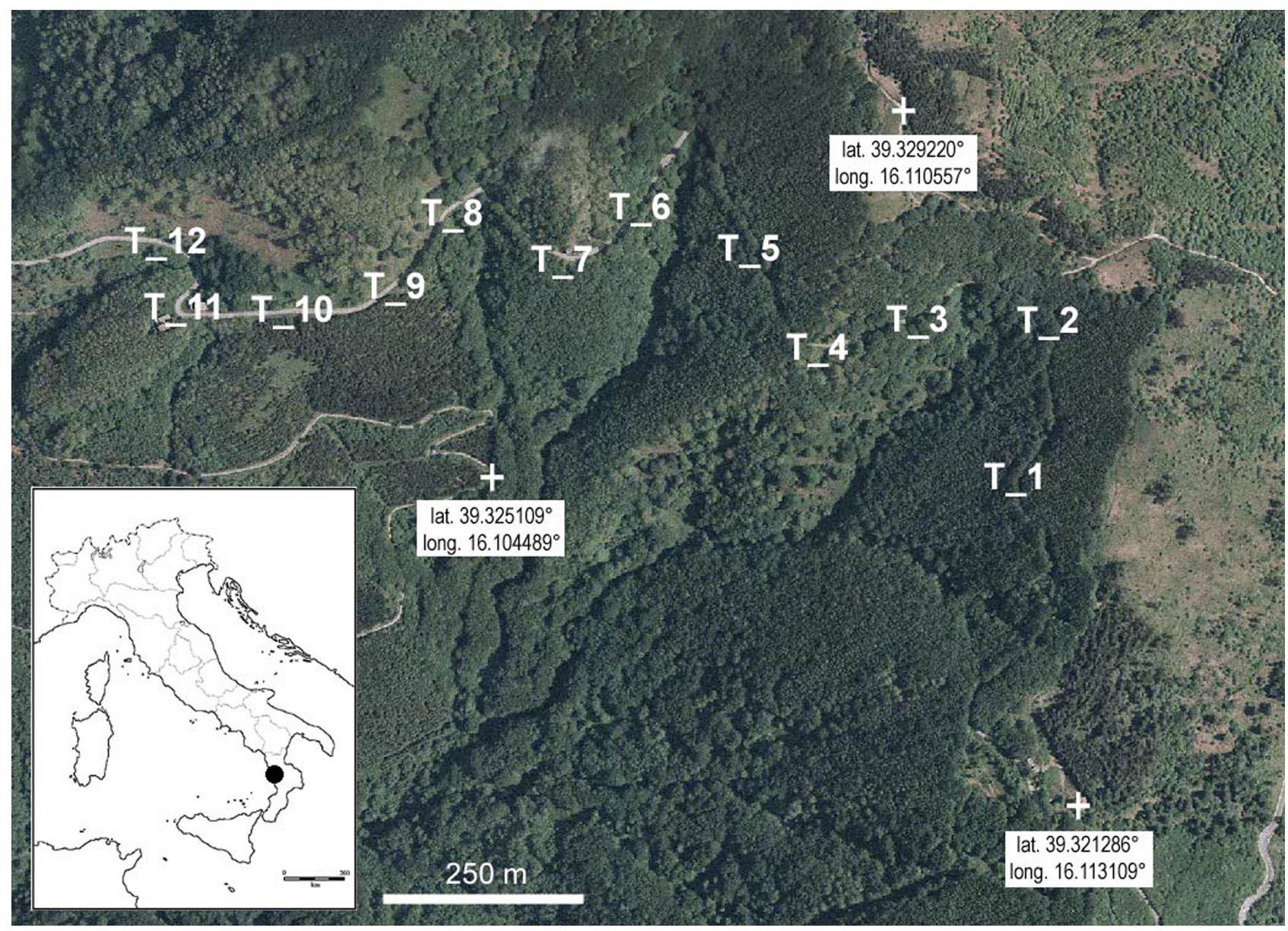

Fig. 1. Map showing the locations of the stands sampled (T_1-T_12) in this study. Bags spun by pupating Psychidae were collected from guard rails along Provincial Road n. 35.

that can affect lepidopteran communities in studies carried out at larger scales (Summerville et al., 2003).

Species composition of the tree layer was analyzed in terms of species richness $\left(S_{\text {trees }}\right)$ and beech dominance, with the last expressed in terms of the incidence of beech in the tree layer.

The structural forest parameters investigated were: (1) tree density, the number of trees per $\mathrm{ha}^{-1}$ in a given stand; (2) canopy cover, defined as the percentage of the buffer zones covered by tree canopy measured by determining the surface of the understory directly exposed to the sun in June at midday on sunny days; (3) mean tree diameter at breast height (DBH), (4) its standard deviation (DBH SD) and (5) the cumulative basal area (DBH area); (6) above ground wood biomass (AWB) and (7) dead wood biomass of standing deciduous trees (DWB) computed by using volume and yield tables available for beech forest in the study area (Castellani, 1970); (8) number of large deciduous trees per $\mathrm{ha}^{-1}$, identified as those with a DBH $>40 \mathrm{~cm}$ (Blasi et al., 2010). In the area studied this diameter corresponds to trees older than 100 years (Ciancio et al., 2008), a threshold age critical to sustain biodiversity in old-growth forests (Moning \& Müller, 2009). All trees with a diameter $>3.0 \mathrm{~cm}$ were measured.

Furthermore, we measured the extent of "old-growth", a measure used to estimate the status of old-growth forest (Franklin \& Spies, 1991; Bauhus et al., 2009). It was measured by ranking the stands from most to less "old" for the four structural attributes of old-growth: number of large trees, AWB, DWB and standard deviation of DBH. Stands were ranked in terms of the values of any of the old-growth measures from the highest (score 12) to the lowest (score 1). The stand with the lowest sum of scores was the youngest and that with the highest total score the oldest. Conifers were not taken into account in the measure of old-growth because they were planted in the study area. Results of these stand analyses are summarized in Table 2.

\section{Psychidae sampling}

Bags spun by Psychidae were collected every ten days in 2001 and 2013, using the method adopted by Scalercio (2004), from 12 sections of guard rail along Provincial Road n. 35. Guard rails are good places for sampling Psychidae because it is easier to find them there than on bark and rocks because of their cryptic

Table 1. Topographical features and areas of the stands and lengths of guard rail sampled.

\begin{tabular}{lccccc}
\hline Stand & $\begin{array}{c}\text { Altitude } \\
\text { m a.s.I. }\end{array}$ & Latitude & Longitude & $\begin{array}{c}\text { Guard rail } \\
\text { length } \mathrm{m}^{-1}\end{array}$ & Area m \\
\hline T_1 & 980 & $39.326396^{\circ}$ & $16.112780^{\circ}$ & 74 & 3120 \\
T_2 & 975 & $39.327200^{\circ}$ & $16.111928^{\circ}$ & 102 & 3960 \\
T_3 & 960 & $39.326733^{\circ}$ & $16.110663^{\circ}$ & 109 & 4170 \\
T_4 & 955 & $39.326521^{\circ}$ & $16.109215^{\circ}$ & 50 & 2400 \\
T_5 & 950 & $39.327558^{\circ}$ & $16.108316^{\circ}$ & 160 & 5700 \\
T_6 & 945 & $39.328270^{\circ}$ & $16.106873^{\circ}$ & 66 & 2880 \\
T_7 & 930 & $39.327657^{\circ}$ & $16.105285^{\circ}$ & 51 & 2430 \\
T_8 $^{\circ}$ & 930 & $39.327736^{\circ}$ & $16.103586^{\circ}$ & 45 & 2220 \\
T_9 & 915 & $39.327039^{\circ}$ & $16.102645^{\circ}$ & 63 & 2790 \\
T_10 $^{\circ}$ & 905 & $39.326944^{\circ}$ & $16.101066^{\circ}$ & 178 & 5340 \\
T_11 $^{\circ}$ & 905 & $39.327296^{\circ}$ & $16.099949^{\circ}$ & 67 & 2895 \\
T_12 $^{\circ}$ & 900 & $39.327774^{\circ}$ & $16.099423^{\circ}$ & 63 & 2775
\end{tabular}


Table 2. Evaluation of forest variables recorded at the stands studied.

\begin{tabular}{|c|c|c|c|c|c|c|c|c|c|c|c|c|}
\hline \multirow{2}{*}{ Forest variables } & \multicolumn{12}{|c|}{ Stands } \\
\hline & $T_{-1}$ & T_2 & T_3 & $T_{-} 4$ & T_5 & T_6 & $T_{-} 7$ & T_8 & T_9 & T_10 & T_11 & $T_{-12}$ \\
\hline Tree species richness $\left(S_{\text {trees }}\right)$ & 3 & 2 & 4 & 6 & 6 & 4 & 7 & 7 & 7 & 9 & 9 & 4 \\
\hline Beech dominance $(0-1)$ & 0.90 & 1.00 & 0.71 & 0.84 & 0.85 & 0.93 & 0.61 & 0.28 & 0.64 & 0.08 & 0.09 & 0.04 \\
\hline Tree density $\left(\mathrm{ha}^{-1}\right)$ & 369 & 189 & 158 & 475 & 398 & 840 & 1461 & 689 & 789 & 464 & 183 & 281 \\
\hline Canopy cover (\%) & 96.2 & 98.7 & 71.5 & 96.7 & 98.4 & 92.5 & 80.2 & 61.3 & 61.6 & 73.1 & 70.5 & 60.6 \\
\hline $\mathrm{DBH}(\mathrm{cm})$ & 31.3 & 52.5 & 27.3 & 26.0 & 27.9 & 12.8 & 11.3 & 12.1 & 14.4 & 25.9 & 35.0 & 22.1 \\
\hline DBH_SD (cm) & 26.59 & 28.49 & 28.54 & 21.99 & 24.45 & 12.84 & 9.27 & 11.03 & 12.16 & 13.05 & 19.92 & 11.13 \\
\hline $\mathrm{DBH}$ area $\left(\mathrm{m}^{2}\right)$ & 40.97 & 43.62 & 22.26 & 42.59 & 44.17 & 21.67 & 24.46 & 18.41 & 20.46 & 35.76 & 23.04 & 13.37 \\
\hline Large trees (tree ha ${ }^{-1}$ ) & 134.6 & 133.8 & 55.16 & 129.2 & 121.1 & 59.03 & 28.81 & 49.55 & 35.84 & 16.85 & 62.18 & 21.62 \\
\hline AWB $\left(\mathrm{m}^{3} \mathrm{ha}^{-1}\right)$ & 454 & 517 & 158 & 448 & 445 & 196 & 165 & 154 & 175 & 265 & 252 & 120 \\
\hline DWB $\left(m^{3} h^{-1}\right)$ & 1.71 & 0.45 & 0.15 & 2.85 & 0.558 & 0 & 5.646 & 0.144 & 0.019 & 0 & 0 & 0.472 \\
\hline Old-growthness (score) & 43 & 41 & 34 & 38 & 35 & 18 & 19 & 14 & 16 & 15 & 22 & 14 \\
\hline
\end{tabular}

colouring and because many species pupate on guard rails. In fact, several Psychidae pupate on vertical surfaces, usually trees, plants, rocks but also guard rails, in order to maximize mating success (Rhainds et al., 1995) and dispersal of the young larvae that emerge from the bags (Ghent, 1999). The pupation sites of the different sexes of some species of bagworm differ (Rhainds et al., 2009) and collecting bags can result in underestimates of the numbers of species and of the different sexes, usually the males, which pupate on horizontal surfaces. The data, however, are suitable for ecological analyses because they are collected in a standardized way. Sampling along guard rails is similar to sampling along forest edges or in forest gaps and such habitats, as they could differ greatly in terms their microclimate compared to adjacent forest. However, the stands studied were in a buffer zone around guard rails, which was large enough to include all these habitat discontinuities. Usually, there are no gaps in the canopy of stands with large trees because their crowns are very large, which results in a relatively uniform microclimate in these forests.

All bags were removed from the guard rails and tentatively identified to species level in the field. Then, they were kept singly in aerated transparent plastic tubes under laboratory conditions of light and temperature until adults, larvae or parasitoids emerged. Species identification was confirmed after adult emergence based on the morphology of the adults and genital apparatus of males using specialist keys (Kozhanchikov, 1956; Hättenschwiler, 1985; Hättenschwiler, 1997, and references therein), and by barcoding analysis (available in the BOLD dataset "DSPSYFO", accessed at http://dx.doi.org/10.5883/DS-PSYFOR)

Table 3. Summary of the Psychidae collected in the different stands. For each species the total number of bags collected in $2001\left(N_{2001}\right)$ and in $2013\left(N_{2013}\right)$, and the mean number of bags collected per meter on guard rails during the whole sampling period $(2001+2013)$ were recorded.

\begin{tabular}{|c|c|c|c|c|c|c|c|c|c|c|c|c|c|}
\hline \multirow{2}{*}{ Species } & & \multicolumn{12}{|c|}{ Stands } \\
\hline & & T_1 & T_2 & T_3 & T_4 & T_5 & T_6 & T_7 & T_8 & T_9 & T_10 & T_11 & T_12 \\
\hline \multirow{3}{*}{$\begin{array}{l}\text { Taleporia } \\
\text { defoliella }\end{array}$} & $N_{2001}$ & 223 & 106 & 118 & 78 & 93 & 48 & 3 & 2 & 6 & 0 & 0 & 0 \\
\hline & $N_{2013}$ & 88 & 205 & 43 & 12 & 79 & 16 & 6 & 8 & 4 & 0 & 0 & 0 \\
\hline & bags $\mathrm{m}^{-1}$ & 2.1 & 1.5 & 0.74 & 0.90 & 0.54 & 0.49 & 0.09 & 0.11 & 0.08 & 0 & 0 & 0 \\
\hline \multirow{3}{*}{$\begin{array}{l}\text { Taleporia } \\
\text { tubulosa }\end{array}$} & $N_{2001}$ & 3 & 17 & 2 & 6 & 22 & 8 & 1 & 1 & 9 & 23 & 7 & 14 \\
\hline & $N_{2013}$ & 5 & 17 & 26 & 17 & 47 & 15 & 11 & 15 & 18 & 32 & 15 & 11 \\
\hline & bags $\mathrm{m}^{-1}$ & 0.05 & 0.17 & 0.13 & 0.23 & 0.22 & 0.17 & 0.12 & 0.18 & 0.21 & 0.15 & 0.16 & 0.20 \\
\hline \multirow{3}{*}{$\begin{array}{l}\text { Psyche } \\
\text { crassiorella }\end{array}$} & $N_{2001}$ & 5 & 23 & 39 & 13 & 51 & 35 & 31 & 33 & 27 & 41 & 4 & 8 \\
\hline & $N_{2013}$ & 2 & 6 & 27 & 27 & 35 & 19 & 59 & 34 & 79 & 149 & 19 & 82 \\
\hline & bags $\mathrm{m}^{-1}$ & 0.05 & 0.14 & 0.30 & 0.40 & 0.27 & 0.41 & 0.88 & 0.74 & 0.84 & 0.53 & 0.17 & 0.71 \\
\hline \multirow{3}{*}{$\begin{array}{l}\text { Anaproutia } \\
\text { comitella }\end{array}$} & $N_{2001}$ & 25 & 11 & 26 & 12 & 19 & 2 & 22 & 9 & 11 & 6 & 0 & 0 \\
\hline & $N_{2013}$ & 11 & 20 & 17 & 28 & 24 & 15 & 30 & 0 & 20 & 24 & 2 & 1 \\
\hline & bags $\mathrm{m}^{-1}$ & 0.24 & 0.15 & 0.20 & 0.40 & 0.13 & 0.13 & 0.51 & 0.10 & 0.25 & 0.08 & 0.02 & 0.01 \\
\hline \multirow{3}{*}{$\begin{array}{l}\text { Bankesia } \\
\text { conspurcatella }\end{array}$} & $N_{2001}$ & 0 & 2 & 0 & 0 & 0 & 1 & 0 & 0 & 1 & 0 & 0 & 1 \\
\hline & $N_{2013}$ & 11 & 13 & 3 & 4 & 2 & 0 & 0 & 1 & 1 & 0 & 0 & 0 \\
\hline & bags $\mathrm{m}^{-1}$ & 0.07 & 0.07 & 0.01 & 0.04 & 0.01 & 0.01 & 0 & 0.01 & 0.02 & 0 & 0 & 0.01 \\
\hline \multirow{3}{*}{$\begin{array}{l}\text { Canephora } \\
\text { unicolor }\end{array}$} & $N_{2001}$ & 0 & 0 & 0 & 0 & 0 & 0 & 0 & 2 & 2 & 4 & 0 & 2 \\
\hline & $N_{2013}$ & 0 & 0 & 0 & 0 & 0 & 1 & 1 & 0 & 4 & 0 & 0 & 4 \\
\hline & bags $\mathrm{m}^{-1}$ & 0 & 0 & 0 & 0 & 0 & 0.01 & 0.01 & 0.02 & 0.05 & 0.01 & 0 & 0.05 \\
\hline \multirow{3}{*}{$\begin{array}{l}\text { Luffia } \\
\text { lapidella }\end{array}$} & $N_{2001}$ & 0 & 0 & 0 & 0 & 0 & 1 & 2 & 0 & 0 & 1 & 0 & 0 \\
\hline & $N_{2013}$ & 0 & 0 & 0 & 0 & 0 & 1 & 0 & 0 & 0 & 0 & 0 & 0 \\
\hline & bags $\mathrm{m}^{-1}$ & 0 & 0 & 0 & 0 & 0 & 0.02 & 0.02 & 0 & 0 & 0.01 & 0 & 0 \\
\hline \multirow{3}{*}{$\begin{array}{l}\text { Phalacropteryx } \\
\text { apiformis }\end{array}$} & $N_{2001}$ & 0 & 0 & 0 & 0 & 0 & 0 & 0 & 1 & 1 & 2 & 0 & 0 \\
\hline & $N_{2013}$ & 0 & 0 & 0 & 0 & 0 & 0 & 0 & 0 & 0 & 0 & 0 & 0 \\
\hline & bags $\mathrm{m}^{-1}$ & 0 & 0 & 0 & 0 & 0 & 0 & 0 & 0.01 & 0.01 & 0.01 & 0 & 0 \\
\hline
\end{tabular}


Table 4. Similarity of the samples collected in 2001 and 2013 Similarity of stands and species in the two samples was measured using Morisita-Horn similarity index $(M-H)$.

\begin{tabular}{lccc}
\hline Stands & $M-H$ & Species & $M-H$ \\
\hline T_1 & 0.982 & T. defoliella & 0.759 \\
T_2 & 0.987 & T. tubulosa & 0.877 \\
T_3 & 0.825 & P. crassiorella & 0.735 \\
T_4 & 0.868 & A. comitella & 0.824 \\
T_5 & 0.958 & B. conspurcatella & 0.569 \\
T_6 & 0.716 & C. unicolor & 0.516 \\
T_7 & 0.971 & L. lapidella & 0.363 \\
T_8 & 0.875 & P. apiformis & 0 \\
T_9 & 0.973 & & \\
T_10 & 0.933 & & \\
T_11 & 0.921 & & \\
T_12 & 0.586 & & \\
\hline
\end{tabular}

(Ratnasingham \& Hebert, 2007). All sequences are also available on GenBank (accession numbers: KU497313, KU497314, KU497407, KU497421-KU497423). Data on species presence and abundance were recorded on data sheets. Empty bags from which adults emerged were identified based on their structure. Some voucher specimens were retained in the collection of the Unità di Ricerca per la Selvicoltura in Ambiente Mediterraneo and the others were released alive in the field.

\section{Data analysis}

A Psychidae species/stand matrix was built using the number of bags per meter of guard rail as a measure of abundance, which is recorded in the matrix and submitted to statistical analyses.

A previous study (Scalercio, 2004) recorded seven species in the study area. Among them, Taleporia defoliella and Anaproutia comitella, the last erroneously identified as Proutia betulina, are recorded only from northern Italy. The analysis of the diversity of Psychidae communities was done using species richness, a diversity measure often used in studies on arthropod communities (e.g. Usher \& Keiller, 1998; Summerville et al., 2004; Blasi et al., 2010; Negro et al., 2013; Redolfi De Zan et al., 2014).

Pairwise similarities of the 2000 and 2013 samples were evaluated using Morisita-Horn index $(M-H)$, a quantitative similarity index based on species abundances, ranging from 0 for completely different communities to 1 in the case of identical communities (Magurran, 1988). We used a quantitative index in our analyses because it is more appropriate for comparing species poor communities. Cumulative and individual communities sampled in 2000 and 2013 were compared in order to assess if significant changes had occurred and to evaluate if combining them in a unique species/stands matrix was appropriate. Comparisons were done using EstimateS 9.1.0 (Colwell, 2013).

Species and communities were grouped using Cluster Analysis. This method groups variables that have similar distributional patterns or composition. We used Complete Linkage clustering as the amalgamation method, 1-Pearson $r$ to measure the distances between species, a measure not sensitive to the abundance of the rarest species and the Chebychev metric to measure the distances between communities. We ran a Canonical Correspondence Analysis (CCA) on the standardized species/stand matrix. The $\mathrm{CCA}$ is a multivariate statistical technique that identifies latent relationships between stands and species and determines the most important factors shaping community composition. This analysis displays a set of data, species and stands in two-dimensional graphical form (bi-plot) based on the percentage of inertia (total variance) explained by the most relevant axes or dimensions. Species and stands that are close on the bi-plot have a tenden-

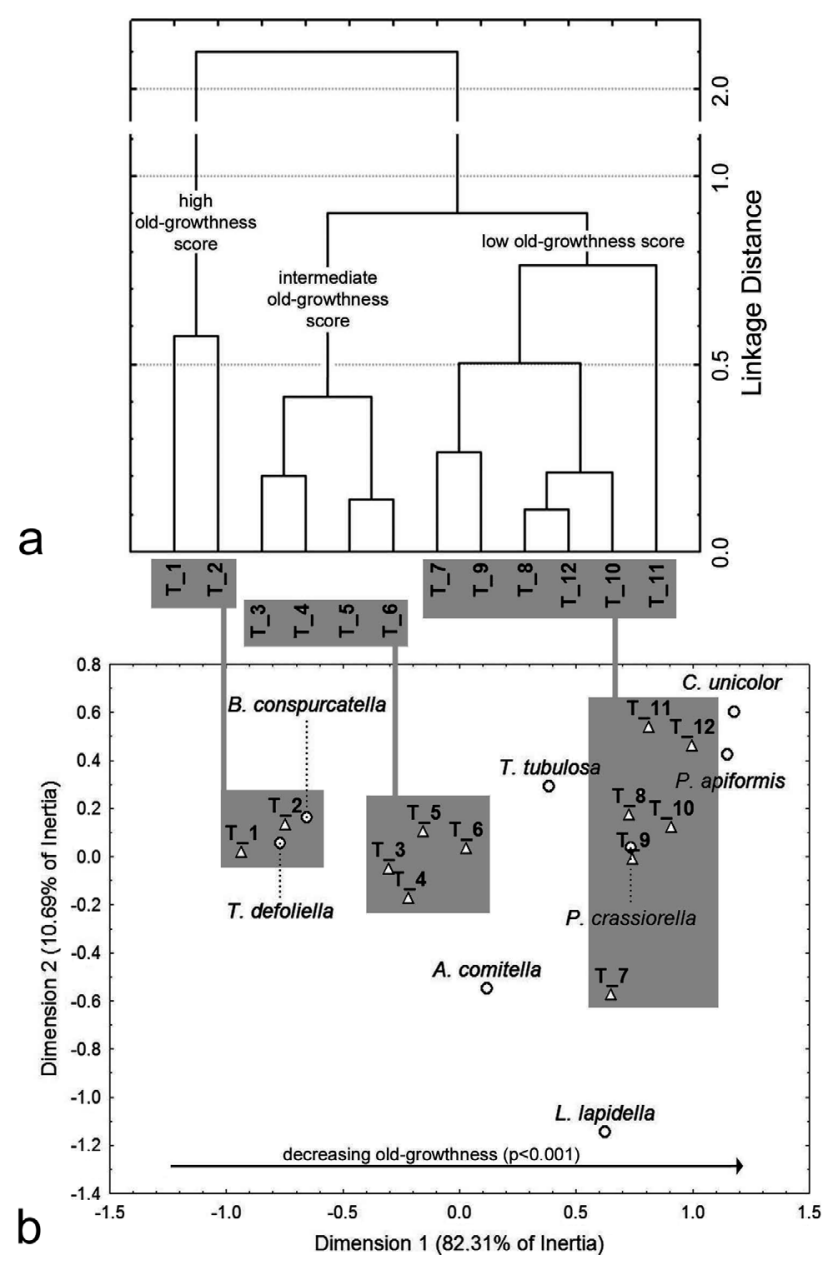

Fig. 2. Results of multivariate analyses: a - Cluster Analysis of the Psychidae communities sampled (Complete Linkage method, Chebychev metric distances); $b$ - distribution of stands and species on the CCA bi-plot defined in terms of dimensions 1 and 2 that account for $93 \%$ of the total inertia.

cy to be associated with each other, i.e. these species tend to be most abundant in these stands. Dimension 1 and 2 represent the most relevant factors determining the observed patterns. In order to identify the ecological meaning of these dimensions, we carried out a correlation analysis (non parametric Spearman Rank Correlation) of the relationships between forest parameters of the stands and their scores on Dimension 1 and 2.

To assess if correlations occur between Psychidae and forest structure, the non parametric Spearman Rank Correlation was chosen as the most appropriate statistical procedure. Results were submitted to a correction for multiple comparisons according to the Bonferroni rule. The response variables were the total abundance $\left(N_{\text {Psy }}\right)$ and species richness $\left(S_{\text {Psy }}\right)$ of the Psychidae communities with abundances (bags per meter) of individual species making up more than $1 \%$ of the total Psychidae abundance; forest attributes were treated as explanatory variables. Statistical analyses were computed using STATISTICA 8.0 (StatSoft Inc.).

\section{RESULTS}

\section{Psychidae communities}

We collected 2,732 bags, 1,185 in 2001 and 1,547 in 2013. Communities were made up of 8 species (Table 3), of which only Phalacroperix apiformis was absent in 2013. This species usually occurs at lower altitudes and in more 
Table 5. Non parametric Spearman pairwise Rank Correlation coefficient of Psychidae communities with forest attributes $\left(N_{\text {Psy }}-\right.$ total abundance of Psychidae communities; $S_{\text {Psy }}$ - species richness of Psychidae communities; $\left.{ }^{*} p<0.05\right)$ and individual species making up more than the $1 \%$ of the total Psychidae abundance.

\begin{tabular}{lcccrrr}
\hline Forest attributes & $N_{\text {Psy }}$ & $S_{\text {Psy }}$ & $\begin{array}{c}\text { Taleporia } \\
\text { defoliella }\end{array}$ & $\begin{array}{c}\text { Psyche } \\
\text { crassiorella }\end{array}$ & $\begin{array}{c}\text { Anaproutia } \\
\text { comitella }\end{array}$ & $\begin{array}{c}\text { Taleporia } \\
\text { tubulosa }\end{array}$ \\
\hline Tree density & 0.17 & 0.81 & -0.14 & 0.70 & 0.38 & 0.20 \\
conspurcatella
\end{tabular}

xeric habitats and probably was rare and only occasionally present in the study area. Taleporia defoliella $(41.7 \%$ of the whole community) was the most abundant species followed by Psyche crassiorella (31.0\%), Taleporia tubulosa (12.5\%) and Anaproutia comitella (12.3\%), but only the last three species were recorded in all stands (Table 3).

Cumulative communities sampled in 2001 and 2013 are very similar $(M-H=0.933)$, in terms of Taleporia defoliella, T. tubulosa, Psyche crassiorella and Anaproutia comitella $(0.735<M-H<0.877)$. Bankesia conspurcatella, Canephora unicolor and Luffia lapidella showed a different pattern between years $(0.363<M-H<0.569)$ and only accounted for $2.97 \%$ in 2013 and $1.94 \%$ in 2001 of the cumulative species assemblage. The communities recorded in 2001 and 2013 were similar $(0.586<M-H<0.982$, two communities with $M-H<0.825$ ) (Table 4). These results indicate that there was little variation between the years sampled allowing us to merge the data collected within a species/stand matrix that incorporates natural annual variations in population abundances.

Cluster Analysis grouped communities in three different clusters (Fig. 2a). One cluster included stands $T_{-} 1$ and T_2, with high densities of large trees, high AWB and high old-growth scores (see Table 2). Another cluster included four stands, T_3 to T_6, in which beech was dominant and with intermediate values of large tree density, AWB and old-growth scores. Last cluster included the most perturbed stands with low dominance of beech and low oldgrowth scores (Fig. 2a).

Results of the CCA were consistent with those of the Cluster Analysis confirming the existence of three groups of communities. Dimension 1 and 2 explained $82.31 \%$ and $10.69 \%$ of the total inertia, respectively (Fig. 2b). In the bidimensional space individuated by the first two dimensions, B. conspurcatella and T. defoliella are strictly associated with stands T_1 and T_2 and $P$. crassiorella, $P$. apiformis and $C$. unicolor with stands $\mathrm{T}_{-} 8$ to $\mathrm{T}_{-} 12 . \mathrm{T}_{-} 1$ and T_2 had the best old-growth scores, whilst old-growth scores of T_8-T_12 were very low (Table 2). Old-growth was best correlated with dimension $1\left(r_{\mathrm{s}}=-0.86 ; p<0.001\right.$; $N=12)$ and DWB with dimension $2\left(r_{\mathrm{s}}=-0.51 ; p=\mathrm{NS}\right.$; $N=12)$.

\section{Correlations of Psychidae with forest variables}

Correspondence Analysis indicate that old-growth was the main determinant of species distribution and community composition. Non parametric Spearman Rank Correlation coefficients revealed the forest parameters that influenced Psychidae communities and individual species (Table 5). Canephora unicolor, Luffia lapidella and Phalacropterix apiformis were excluded from this analysis because their abundance is lower than $1 \%$. Species richness and abundance of communities were not significantly correlated with forest parameters, unlike Taleporia tubulosa, Anaproutia comitella and Bankesia conspurcatella.

The two most abundant species differed in their association with particular forest attributes. Taleporia defoliella was positively associated with stands with some of the features of old-growth forests, and positively correlated with beech dominance and density of large trees $(\mathrm{p}<0.05)$ (Table 5). In contrast, Psyche crassiorella was negatively associated with stands with some of the features of oldgrowth forests and significantly negative correlated with DBH and DBH_SD $(\mathrm{p}<0.05)$.

\section{DISCUSSION}

Structural attributes of beech forests, especially those characteristic of old-growth forests, significantly influenced the distribution of species and composition of Psychidae communities. In fact, old growth forest, measured using the main parameters of old growth forests (Bauhus et al., 2009), accounted for most of the variation recorded in Psychidae communities. Diameter at breast high, its standard deviation, beech dominance and number of large trees were the main determinants driving distribution at the species level, whilst species richness and total abundance was not correlated with any individual forest attributes.

Diversity of species is associated to different degrees with several forest attributes depending on the life history traits and perception scale of the species. The literature indicates that diversity measures are useful tools for exploring present and past ecological dynamics (Usher \& Keiller, 1998; Summerville \& Crist, 2003; Summerville et al., 2009; Blasi et al., 2010; Rosenvald et al., 2011; Negro et al., 2013). This did not happen for Psychidae as there 
are only a few species and abundance would be a more useful measure for searching for forest correlates. Abundance in animals is usually associated with an abundance food as is recorded for birds (Rosenvald et al., 2011) and saproxilic beetles (Redolfi De Zan et al., 2014). Nevertheless, in this study the opposite ecological needs of the two most abundant species concealed the relationships between forests and abundance at the community level. At the species level abundance of Taleporia defoliella was positively correlated with forest attributes. Beech dominance, and number of large trees probably indirectly affect food availability because it is reported that lichens and mosses, the main source of food for this species (Hättenschwiler \& Scalercio, 2003), are more abundant in old-growth forests (Kuusinen \& Siitonen, 1998; Botting \& Fredeen, 2006).

Psyche crassiorella was also correlated with above mentioned forest attributes but rather than positively correlated as in the case of $T$. defoliella it was negatively correlated with them.

Forest attributes positively correlated with Taleporia defoliella affect the diversity of other taxa in beech forests (Moning \& Müller, 2009). Among other attributes the number of large trees is of special interest as they usually provide microhabitats that enhance forest biodiversity (Michel \& Winter, 2008; Fritz \& Heilmann-Clausen, 2010), especially that of lichens and bryophytes (Fritz \& Heilmann-Clausen, 2010) on which many species of Psychidae feed. Furthermore, both these attributes are easily recognizable during a rapid assessment of forest and provide a quick picture of the extent of old-growth in a given forest. Taleporia defoliella is also significantly correlated with beech dominance, but this is probably due only to the high extent of old-growth in the beech forests sampled, not to a relationship with this particular species of tree. In fact, it is also abundant in a mature woodland of Castanea sativa and Alnus cordata in the same area as the current study and in other mountainous forested habitats in Calabria, southern Italy (Scalercio, 2004, 2009). Although not significant, a negative association with tree species richness was recorded for this species. Increase in tree diversity in monophytic beech forests seems to be a response to moderate environmental perturbations especially at the beginning of the regeneration process (Barna \& Bosela, 2015).

Psyche crassiorella is a widely distributed species occurring in several habitats (Hättenschwiler, 1997). Although it occurred in all the stands sampled it was particularly abundant in those with little old-growth (Table 4).

Naturally occurring gaps in forest cover are associated with a higher overall biodiversity (McCarthy, 2001; Getzin et al., 2012), due to the creation of microclimatic discontinuities mainly in terms of temperatures and light at soil level. These environmental conditions are favourable for $P$. apiformis and $C$. unicolor, which were associated with young forests stages in this study (Fig. 2), usually occurring in open areas and at lower altitudes (Scalercio, 2009). On the other hand, low abundances of T. defoliella are associated with these condition as this species occurs in mature stands and is vulnerable to extensive alterations in forest cover. Inappropriate forest management such as clear cutting and other strategies that modify forests cover over large areas could have a great effect on this species. Our data support sustainable forest management based on selective thinning that promote the formation of small gaps in forest cover, which are not detrimental to forest biodiversity (Peck et al., 2005; Wilson et al., 2007). Although Lepidoptera are largely used as ecological indicators of forest habitats (Usher \& Keiller, 1998; Summerville \& Crist, 2003; Summerville et al., 2013), and can be used to describe present and past ecosystem dynamics at different scales (Wilson et al., 2005; Scalercio et al., 2012), they have never been previously used to investigate the association of biodiversity with the structural attributes of forests. This is mainly because of the high dispersal power of the adults makes investigating patterns at a very small scale very difficult. Caterpillars have a very low dispersal power and are used to explore ecological dynamics at smaller scales than is possible using adults (Bodner et al., 2012). Unfortunately, sampling larvae is difficult because they (1) fall to the ground when disturbed, (2) are active only during the night resting on the soil in daytime, (3) are difficult to identify to species level, etc. Natural history of Psychidae, mainly the persistence of bags at pupation sites for several weeks or months after adult emergence, and the lack of feeding specializations of a large proportion of the species, allowed us to investigate more intimately than for other lepidopteran taxa their relationships with individual structural forest attributes.

\section{CONCLUSIONS}

In this paper species belonging to the family of Psychidae were used for the first time in an ecological study that demonstrates they can be used as descriptors of forest habitats. Relationships of Psychidae communities and species with forest attributes can be simply summarized in terms of the significance of old-growth. This study confirmed the importance of old-growth forest attributes for diversity conservation for a little studied group, the Psychidae, which are an important part of forest biodiversity and should not be neglected in the future. In particular, beech forests in the Mediterranean mountains are important for the conservation of regional diversity and there is an increasing need for forest planning that encompasses the preservation of attributes associated with old-growth forests, especially those easily recognizable such as the number of large trees.

ACKNOWLEDGEMENTS. SS, TB, RT and VB carried out the field measurements, SS and RT performed the statistical analysis, TB helped to draft the manuscript, SS conceived the study and drafted the manuscript. We thank E. Fezza, G. Iannuzzi, T. Aloe and C. Di Marco for their help with field work, and L. Salvati for his help with the statistical analyses. This work was funded by Project PON03PE_00024_1 (Ambi.Tec.Fil.Legno-AlForLab).

\section{REFERENCES}

Barbati A., Marchetti M., Chirici G. \& Corona P. 2014: European forest types and forest Europe SFM indicators: tools for monitoring progress of forest biodiversity conservation. Forest Ecol. Manag. 321: 145-157. 
Barna M. \& Bosela M. 2015: Tree species diversity change in natural regeneration of a beech forest under different management. — Forest Ecol. Manag. 342: 93-102.

Bauhus J., Puettmann K. \& Messier C. 2009: Silviculture for old-growth attributes. — Forest Ecol. Manag. 258: 525-537.

Blasi C., Marchetti M., Chiavetta U., Aleffi M., Audisio P., Azzella M.M., Brunialti G., Capotorti G., Del Vico E., Lattanzi E., Persiani A.M., Ravera S., Tilia A. \& Burrascano S. 2010: Multi-taxon and forest structure sampling for identification of indicators and monitoring of old-growth forest. — Plant Biosyst. 144: 160-170.

Bodner F., Strutzenberger P., Brehm G. \& Fiedler K. 2012: Species richness and host specificity among caterpillar ensembles on shrubs in the Andes of southern Ecuador. - Neotrop. Entomol. 41: 375-385.

Bonacci T., Mazzei A., Horák J. \& Brandmayr P. 2012: Cucujus tulliae sp. n. - an endemic Mediterranean saproxylic beetle from genus Cucujus Fabricius, 1775 (Coleoptera, Cucujidae), and keys for identification of adults and larvae native to Europe. - ZooKeys 212: 63-79.

Botting R.S. \& FREDEEN A.L. 2006: Contrasting terrestrial lichen, liverwort, and moss diversity between old-growth and young second-growth forest on two soil textures in central British Columbia. - Can. J. Bot. 84: 120-132.

Castellani C. 1970: Tavole stereometriche ed alsometriche costruite per boschi italiani. - Ann. Ist. Sper. Assest. Forest. Alpicolt. 1: 1-431.

Cherkaoui I., Selmi S., Boukhriss J., Rguibi-Idrissi H. \& DakKI M. 2009: Factors affecting bird richness in a fragmented cork oak forest in Morocco. - Acta Oecol. 35: 197-205.

Ciancio O. 1971: Sul clima e sulla distribuzione altimetrica della vegetazione forestale in Calabria. - Ann. Ist. Sper. Selvicolt. 2: $321-372$.

Ciancio O., Iovino F., Menguzzato G. \& Nicolaci A. 2008 Struttura e trattamento in alcune faggete dell'Appennino meridionale. - Italia Forest. Mont. 6: 465-481.

Colwell R.K. 2013: EstimateS: Statistical Estimation of Species Richness and Shared Species from Samples. Version 9. URL: purl.oclc.org/estimates.

FrANKLIN J.F. \& SPIES T.A. 1991: Ecological definitions of oldgrowth douglas fir forests. In Wildlife and Vegetation of Unmanaged Douglas - Fir Forests. Gen. Tech. Rep. PNW-GTR-285. Portland, OR: USDA, Forest Service, Pacific Northwest Forest and Range Experiment Station, pp. 61-69.

Fritz Ö. \& Heilmann-Clausen J. 2010: Rot holes create key microhabitats for epiphytic lichens and bryophytes on beech (Fagus sylvatica). - Biol. Conserv. 143: 1008-1016.

Fuentes-Montemayor E., Goulson D., Cavin L., Wallace J.M. \& PARK K.J. 2012: Factors influencing moth assemblages in woodland fragments on farmland: Implications for woodland management and creation schemes. - Biol. Conserv. 153: $265-275$.

Getzin S., Wiegand K. \& SchönIng I. 2012: Assessing biodiversity in forests using very high-resolution images and unmanned aerial vehicles. - Meth. Ecol. Evol. 3: 397-404

GHENT A.W. 1999: Studies of ballooning and resulting patterns of locally contagious distribution of the bagworm Thyridopteryx ephemeraeformis (Haworth) (Lepidoptera: Psychidae). - Am. Midl. Nat. 142: 291-313.

HätTEnsChwiler P. 1985: Psychidae. In Emmet A.M. \& Heath J. (eds): The Moths and Butterflies of Great Britain and Ireland. Vol. 2, Cossidae - Heliodinidae. Harley Books, Colchester, Essex, pp. 128-151.

HättensChwilen P. 1997: Psychidae-Sackträger. In Schmetterlinge und ihre Lebensräume: Arten, Gefährdung, Schutz, Band
2. Schweizerischer Bund für Naturschutz, Fotoroar, Egg, pp. 165-308.

Hättenschwiler P. \& SCALERcio S. 2003: Systematik, Morphologie und Verbreitung von Taleporia defoliella Constant, 1895 comb. rev. (Psychidae). - Nota Lepid. 26: 19-25.

JANSSEn P., HéBert C. \& Fortin D. 2011: Biodiversity conservation in old-growth boreal forest: black spruce and balsam fir snags harbor distinct assemblages of saproxylic beetles. Biodiv. Conserv. 20: 2917-2932.

KozhanchiKov I.V. 1956: Insecta, Lepidoptera, Psychidae. Fauna of the USSR Vol. 3 No. 2. Zoological Institute of the Academy of Science of the USSR. English translation 1969, Smithsonian Institution and National Science Foundation, Washington, DC, $525 \mathrm{pp}$.

KuUSinen M. \& SiItonen J. 1998: Epiphytic lichen diversity in old-growth and managed Picea abies stands in southern Finland. - J. Veg. Sci. 9: 283-292.

Lachat T., Wermelinger B., Gossner M.M., Bussler H., IsacsSON G. \& MÜlLER J. 2012: Saproxylic beetles as indicator species for dead-wood amount and temperature in European beech forests. - Ecol. Indic. 23: 323-331.

MagurRan A.E. 1988: Ecological Diversity and its Measurement. Croom-Helm, London, 179 pp.

MANCINI F. 1966: Carta dei suoli d'Italia. Scala $1: 1.000 .000$. Firenze.

Mazzei A., Bonacci T., Contarini E., Zetto T. \& Brandmayr P. 2011: Rediscovering the "umbrella species" candidate $\mathrm{Cu}$ cujus cinnaberinus (Scopoli, 1763) in southern Italy (Coleoptera: Cucujidae), and notes on bionomy. - Ital. J. Zool. 78: 264-270.

McCARTHY J. 2001: Gap dynamics of forest trees: a review with particular attention to boreal forests. - Environ. Rev. 9: 1-59.

Michel A.K. \& WinTer S. 2008: Tree microhabitat structures as indicators of biodiversity in Douglas-fir forests of different stand ages and management histories in the Pacific Northwest, U.S.A. - Forest Ecol. Manag. 257: 1453-1464.

Moning C. \& MülLER J. 2009: Critical forest age thresholds for the diversity of lichens, molluses and birds in beech (Fagus sylvatica L.) dominated forests. — Ecol. Indic. 9: 922-932.

Negro M., Vacchiano G., Berretti R., Chamberlain D.E., PalESTRIni C., Motta R. \& Rolando A. 2013: Effects of forest management on ground beetle diversity in alpine beech (Fagus sylvatica L.) stands. - Forest Ecol. Manag. 328: 300-309.

New T.R. 2004: Moths (Insecta: Lepidoptera) and conservation: background and perspective. - J. Insect Conserv. 8: 79-94.

Nieto A. \& Alexander K.N.A. 2010: European Red List of Saproxylic Beetles. Publications Office of the European Union, Luxembourg, $45 \mathrm{pp}$.

OstafF D.P. \& Quiring D.T. 2000: Role of host plant in the decline of populations of a specialist herbivore, the spruce bud moth. - J. Anim. Ecol. 69: 263-273.

Peck R.W. \& Niwa C.G. 2005: Longer-term effects of selective thinning on microarthropod communities in a late-successional coniferous forest. - Environ. Entomol. 34: 646-655.

Ratnasingham S. \& Hebert P.D.N. 2007: BOLD: The Barcode of Life Data System (www.barcodinglife.org). - Mol. Ecol. Notes 7: 355-364.

Redolfi De Zan L., Bellotti F., D’Amato D. \& Carpaneto G.M. 2014: Saproxylic beetles in three relict beech forests of central Italy: analysis of environmental parameters and implications for forest management. — Forest Ecol. Manag. 328: 229-244.

Rhainds M., Gries G. \& Chinchilla C. 1995: Pupation site and emergence time influence the mating success of bagworm females, Oiketicus kirbyi. — Entomol. Exp. Appl. 77: 183-187. 
Rhainds M., Davis D.R. \& Price P.W. 2009: Bionomics of bagworms (Lepidoptera: Psychidae). - Annu. Rev. Entomol. 54: 209-226.

Rosenvald R., Lõhmus A., Kraut A. \& Remm L. 2011: Bird communities in hemiboreal old-growth forests: the roles of food supply, stand structure, and site type. - Forest Ecol. Manag. 262: $1541-1550$.

SAGAR R. \& Singh J.S. 2006: Tree density, basal area and species diversity in a disturbed dry tropical forest of northern India: implications for conservation. - Environ. Conserv. 33: 256-262.

SCALERCIO S. 2004: I guardrails stradali come mezzo di campionamento dei Lepidotteri Psichidi: risultati faunistico-ecologici in due aree campione della Catena Costiera Paolana (Calabria, Italia). In: Atti del XIX Congresso nazionale italiano di Entomologia, Catania 10-15 giugno 2002, Vol. 1. pp. 191-196.

SCAlercio S. 2009: Messa a punto delle conoscenze sugli Psychidae di Calabria, Italia meridionale (Lepidoptera, Tineoidea). - Boll. Soc. Entomol. Ital. 141: 163-178.

Scalercio S., Iannotta N. \& Brandmayr P. 2007: The role of semi-natural and abandoned vegetation patches in sustaining lepidopteran diversity in an organic olive orchard. - Bull. Insectol. 60: 13-22.

Scalercio S.. Brandmayr P., Iannotta N., Petacchi R. \& BocCACCIO L. 2012: Correlations between landscape attributes and ecological traits of Lepidoptera communities in olive groves. - Eur. J. Entomol. 109: 207-216.

SoвCZYк T. 2011: Psychidae. World Catalogue of Insects, Vol. 10 Apollo Books, Stenstrup, 467 pp.

Summerville K.S. \& CRIST T.O. 2003: Determinants of lepidopteran community composition and species diversity in eastern deciduous forests: roles of season, eco-region and patch size. - Oikos 100: 134-148.

Summerville K.S., Metzler E.H. \& Crist T.O. 2001: Diversity of Lepidoptera in Ohio at local and regional scales: how heterogeneous is the fauna? - Ann. Entomol. Soc. Am. 94: 583-591.
Summerville K.S., Boulware M.J., Veech J.A. \& Crist T.O. 2003: Spatial variation in species diversity and composition of forest Lepidoptera in eastern deciduous forests of North America. - Conserv. Biol. 17: 1045-1057.

Summerville K.S., Ritter L.M. \& Crist T.O. 2004: Forest moth taxa as indicators of lepidopteran richness and habitat disturbance: a preliminary assessment. - Biol. Conserv. 116: 9-18.

Summerville K.S., Courard-Hauri D. \& Dupont M.M. 2009: The legacy of timber harvest: do patterns of species dominance suggest recovery of lepidopteran communities in managed hardwood stands? - Forest Ecol. Manag. 259: 8-13.

Summerville K.S., LANE J. \& Courard-Hauri D. 2013: Stability in forest lepidopteran communities: how sensitive are pest species to experimental forest management? - Insect Conserv. Divers. 6: $265-275$.

Usher M.B. \& KeILLer S.W.J. 1998: The Macrolepidoptera of farm woodlands: determinants of diversity and community structure. - Biodiv. Conserv. 7: 725-748.

Walentowski H., Müller-Kroehling S., Bergmeier E., Bernhardt-Römermann M., Gossner M.M., Reif A., Schulze E.-D., Bussler H., Strätz C. \& Adelmann W. 2014: Faunal diversity of Fagus sylvatica forests: a regional and European perspective based on three indicator groups. - Ann. Forest Res. 57: 215-231.

Wilson D.S. \& PuetTmann K.J. 2007: Density management and biodiversity in yong Douglas-fir forests: challenges of managing across scales. - Forest Ecol. Manag. 246: 123-134.

Wilson R.J., Gutiérrez D., Gutiérrez J., Martinez D., Agudo R. \& MonserRat V.J. 2005: Changes to the elevational limits and extent of species ranges associated with climate change. - Ecol. Lett. 8: 1138-1146.

Received July 29, 2015; revised and accepted November 9, 2015 Published online January 14, 2016 